\section{Features and Exploitation of Thermal-Mineral Water in the Yugoslav Banat}

Tomić, P.*

Romelić, J.**

\section{Abstract}

Banat is a geographic area which includes the northeast part of Yugoslavia, the west part of Romania and the south part of Hungary. The Yugoslav Banat, which is interesting for our research, includes theeastpart of theVojvodina province, bounded by the rivers Danube and Tisa and the Hungarian and Romanian borders. It covers the space of 9,296 sq $\mathrm{km}$, which is $43.2 \%$ of the total territory of Vojvodina.

Banat is an interesting part of the Pannonian Basin because it offers the possibilities of intensive exploitation of geothermal springs of this area. The springs represent a part of the unique hydro-geothermal system. The paper gives the analyses of the main features of mineral and thermal water in the Yugoslav Banat. It also establishes the localities which have the greatest resources and showsthedegreeofthewaterexploitation forthepurposes of the spaandrecreational tourism. The paper also presents the ideas for improving the financial background of the localities where the water is most intensively used. Apart from tourist reasons for the water exploitation, there are several other possibilities for its usage: in agriculture and aqua-culture, for room heating, as technological water, etc.

Key words: Banat, thermal-mineral water, hydro-geologic systems, spa tourism, recreational tourism

\footnotetext{
* PavleTomić, InstituteofGeography,University of Novi Sad, YU, Novi Sad,Trg Dositeja Obradovića 3

**Jovan Romelić, Institute of Geography, University of Novi Sad, YU, Novi Sad,Trg Dositeja Obradovića 3
}

\section{The subterranean water}

The subterranean water of the area is trapped in the cracks and pores in rocks which make the lithosphere. One part of the water is of the fossil origin, the other is of hydro-meteorologic origin.

The fossil water represent the remains of the former seas, lagoons and lakes. The water is still trapped in the sediments settled long time ago. It should be mentioned that the water has undergone certain chemical and physical changes and, therefore, it can not be observed as the original sample of water from this environment..

Hydro-meteorological water is the water which comes from the atmosphere as rain and snow. A certain amount of this water sink and reaches different levels of depth, which depends on the hydro-geological features of the terrain.

The subterranean water of Banat stays in the hydro-geologic systems which are related to certain stratographical formations. The systems are characterized by special features like: depth and abundance of water collector, chemical structure, physical features, etc. On the basis of geological structure and geotectonic and hydrologic factors, we can distinguish four hydro-geologic systems.

The First Hydro-geologic System includes all the sediments from the surface earth layer to the upper pont, i.e. the Quaternary sediments. It appears on the whole territory of Vojvodina, except for The Fruska Gora and the Vrsac Mountains. Its presence is most obvious in the north and central parts of Banat and on the east of Backa, while it is much thinner in the rest of Vojvodina and, therefore, does not play an important role in supplying of geothermal water. Its thickness varies from $450 \mathrm{~m}$ in the north of Banat to several tens of meters on the fringes of the Pannonian Basin. From the lithological point of view, the First Hydro-geologic System is build from various kinds of clay, sand, grit, coal and sandston. The role of water collectors is performed by different kinds of sand and grit, and the clay has the role of the insulator. The hydrologic system includes freat, artesian and subartesian water. In the same time, it is a system which contains the largest part of free water suitable for exploitation.

Freat water represents the water which lies in the porous ground next to the First System. The water of this system is free for exploitation.

Artesian water can be found between two waterproof layers, under hydrostatic pressure. The zone in which the artesian water is collected includes the Karpaty Mountains, the Dinarides and the Alps. The water runs through the subterranean cracks and flows out either in natural way (through splits in the earth) or artificially (artesian wells).

While the artesian wells were dwelled, it was established that the water springs out to the surface which means that it has positive piesometrical level. Regarding this level, we make a distinction between artesian and subartesian water.

The piesometrical level in Banat is usually higher than the theoretical one (gasdruck system), and it comes from the gas which raise the pressure in the water (e.g. the artesian wells around Jermenovac). On its way up to the surface, the artesian water absorbs certain amount of gas (gaslift system), like in the wells in Boka, Konak, etc.

The system of artesian water in Banat is characterized by the appearance of several water layers. In the area around Zrenjanin, there are five layers full of water. The first one, at the depth of $35-60 \mathrm{~m}$, is placed within the diluvial sediments. The second one is $60-80 \mathrm{~m}$ deep and it is separated from the previous one by a $6-20 \mathrm{~m}$ thick layer of clay. The deepest part of this layer is in the Zrenjanin area; it sinks on the north and rises on the south. The water contains a considerable amount of iron and other materials. The fourth water layer is found at the depth of 135-195 m, and the fifth one $250 \mathrm{~m}$ deep.

By the end of the last century, people started drilling for water in this part of Europe, and in Zrenjanin and its surroundings also. The first well was drilled in 1890 in front of the district of fice. However, at the depth of $320 \mathrm{~m}$ the quality of water was not good enough 
for drinking and it was decided to go on with drilling up to $450 \mathrm{~m}$, which again did not lead to expected results.

Until 1897, three wells were drilled to the third water layer (135-195 m). In 1900 there were nine wells in Zrenjanin, and in 1907, already 18 wells. Just before the World War II, there were 54 public and around 80 private artesian and subartesian wells.

The construction of the water supply in Zrenjanin was started in 1963, and since then, around 20 new wells (115-121 $\mathrm{m}$ deep) were made. In the meanwhile, some of them were closed, as well as all of the old artesian wells.

Apart from Zrenjanin, artesian and subartesian wells were made in Belo Blato (there were 9 public subartesian wells 42-48 $\mathrm{m}$ deep), Ecka (there were 54 public subartesian wells $46-50 \mathrm{~m}$ deep) and some other Banat settlements. Generally, the quality of the artesian water is good. The water temperature can vary significantly. The warmest wells (btw. 19 and $22^{\circ} \mathrm{C}$ ) are the ones in Ovca, Borca, Konak, etc. The temperature of water in the wells of Kikinda, Coka and Novi Knezevac is between 15 and $19^{\circ} \mathrm{C}$. The lowest water temperature $\left(10-15^{\circ} \mathrm{C}\right)$ is measured in the wells of Banatski Dvor, Lukino Selo, Ecka, etc.

The water is hottest in the deepest layers (around $120^{\circ} \mathrm{C}$ ) but one can expect the maximum temperature of $90^{\circ} \mathrm{C}$ when it gets to the surface. The accumulated thermal waters in these layers mostly belong to the $\mathrm{HCO}_{3}$-Na type with the total mineralization of $1-9 \mathrm{~g} / \mathrm{l}$ (most often it is 3-5 $\mathrm{g} / \mathrm{l})$. According to previous results the amount of water that springs out is usually between 7 and $13 \mathrm{l} / \mathrm{s}$, and the maximum is $28 \mathrm{l} / \mathrm{s}$. The temperature of water in the moment when it springs out is usually between 45 and $55^{\circ} \mathrm{C}$. The highest water temperatures were measured in Vrbica, the north Banat $-82^{\circ} \mathrm{C}$, and in Srpska Crnja $-75^{\circ} \mathrm{C}$ (Aksin, Milosavljevic, 1982).

The First Hydro-geologic System in the north and central Banat is considered to be very important because of its wide-spreading water layers and the great amount of water which they hold in reserve. In addition, the First System water is hardly mineralized and, therefore, it does not tend to produce mineral sediments. Its negative influence on the sustainable development is smaller than the influence of water from other hydrologic systems (Milosavljevic, Janeckov, Alimpic, 1984).

The water from this system can be used as thermal-mineral water in recreation, sport, tourism, etc., but also as

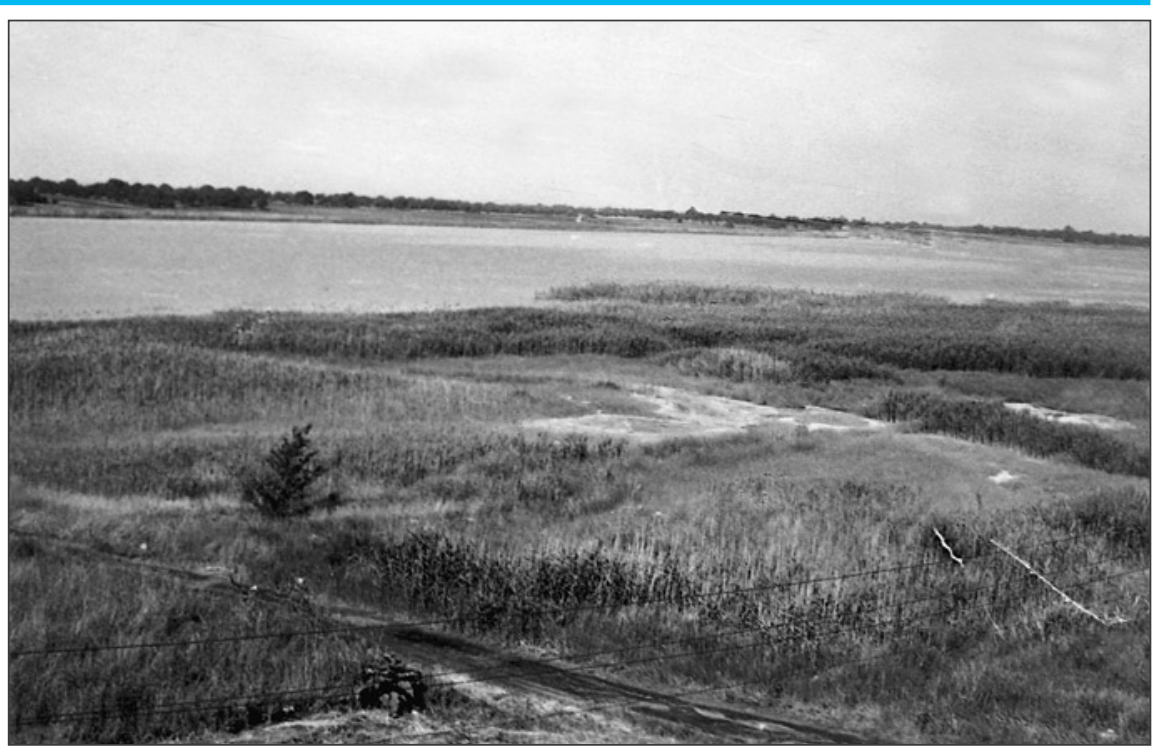

Lake of Rusanda Spa

energy for heating rooms, hot-houses and farms.

The Second Hydro-geologic System is right below the first one and is made of marl, clay, sand, lawer pont and panon. The sand collectors are spread on the north and central Banat with poor possibilities for collecting water. Marl and clay are insulators. The thickness of this layer varies from $1200 \mathrm{~m}$ in the north Banat, to several tens of meters on the fringes of the basin. The previous research has shown that the layers of water are not abundant. Geothermal water from this system belong to the $\mathrm{HCO} 3-\mathrm{Cl}-\mathrm{Na}$ type with the total mineralization of 4-20 g/l, and most commonly it goes from 5 to $12 \mathrm{~g} / \mathrm{l}$. At the places where the sediments of the system are lain deep, the temperature of the water can reach $160^{\circ} \mathrm{C}$, but it does not exceed $100^{\circ} \mathrm{C}$ once the water reaches the surface. The amount of springing water usually varies from $2.5 \mathrm{l} / \mathrm{s}$ to $5 \mathrm{l} / \mathrm{s}$ (maximum $7.3 \mathrm{l} / \mathrm{s}$ ). Usually, the temperature of the springing water is between 50 and $60^{\circ} \mathrm{C}$.

The Third Hydro-geologic System includes collectors (sand and limerock) and insulators (marl, clay). The water is highly mineralized with the total amount of salt in water up to $50 \mathrm{~g} / \mathrm{l}$. The water is aggressive towards metal and cement and it tends to sediment minerals on installations and pipes, which is why it cannot be economically used in heating. Thermal-mineral water of this system belong to the $\mathrm{HCO}_{3}$ - Na type (rarely $\mathrm{Mg}$ and $\mathrm{Ca}$ type) with various therapeutic possibilities of its components (lodine, Fluorine, Bromine, Strontium, etc.) which is why it is suitable for spa treatments. The water temperature in layers varies greatly: it depends on the depth of the layers and geothermal features of the area. The wells usually give between 5-10 l/s of water, maximum 25 $\mathrm{I} / \mathrm{s}$. The temperature of the springing water is between 40 and $50^{\circ} \mathrm{C}$ (Aksin, Milosavljevic).

The Fourth Hydro-geologic System is made of metamorphic rocks of different age and sedimentary rocks from Triassic period. The main distinctive feature of this system is secondary porousity. The most important collectors are Triassic limestone and dolomite with cavities and cracks: they collect a lot of water of low mineralization degree. Thermal-mineral water of this system belongs to $\mathrm{Cl}-\mathrm{Na}$ type or $\mathrm{HCO}_{3}$ $\mathrm{Na}$ type. The total mineralization of the water varies significantly, from highly salty to fresh water. In the isolated zones, the fossil water of this system has the same structure and mineralization as the water of the Third Hydro-geologic System. However, there are some extremely wide zones (Macva, PosavoTamnava, south and east Srem) in which the Fourth System water mixes with the surface water. In the deepest layers the water temperature can reach $120^{\circ} \mathrm{C}$, but when the water gets to the surface the temperature does not exceed $90^{\circ} \mathrm{C}$. The accumulated thermal-mineral water in this system belongs mostly to the $\mathrm{HCO}_{3}$ $\mathrm{Na}$ type with the total mineralization between 1 and $9 \mathrm{~g} / \mathrm{l}$, most commonly 3-5 g/l. According to the previous results, the amount of springing water is between 7 and $13 \mathrm{l} / \mathrm{s}$, maximum $28 \mathrm{l} / \mathrm{s}$. The greatest initial amount was measured in Srpska Crnja (18.3 l/s). The temperature of the springing water is usually between 45 and $55^{\circ} \mathrm{C}$, maximum $82^{\circ} \mathrm{C}$. The highest temperatures were recorded in Vrbica in the north Banat $\left(82^{\circ} \mathrm{C}\right)$ and Srpska Crnja $\left(75^{\circ} \mathrm{C}\right),($ Aksin, Milosavljevic, 1982).

As for exploiting thermal-mineral water for the purposes of heating, the 
water from the First and the Fourth System is the most useful because of its favorable physical and chemical features and the abundance of water in wells and collectors.

The water from the Third and Fourth System are used in spa therapies. For the purposes of sport, recreation and tourism, the most suitable is the water from the First and Fourth System.

\section{Physical and chemical features of thermal-mineral} water and its exploitation

Physical and chemical features of thermal-mineral water are determined by the quantity and quality of minerals and gases, temperature and pressure. The evaluation of these features can be done from two aspects:

a) from the aspect of active physiological and medical effect on human organism

b) from the aspect of limiting factors in the phase of exploitation of thermalmineral water

For the evaluation of medical effects the following criteria are estimated: mineralization, ion structure, contents of therapy active components, contents of gases, radioactivity, active reaction of water $(\mathrm{pH})$ and water temperature (Alimpic, 1989).

General mineralization is an important pharmacological index. The practice has shown that the effect of water on human body is greater if the level of mineralization is higher. In order for the water to affect the human body, the lower limit of mineralization is taken to be $1 \mathrm{~g} / \mathrm{l}$, in some countries, and $2 \mathrm{~g} / \mathrm{l}$, in others.

General mineralization of the thermal-mineral water of Vojvodina moves on the scale from $1 \mathrm{~g} / \mathrm{l}$ to $50 \mathrm{~g} / \mathrm{l}$. It usually depends on the stratographic position of the collectors and the intensity of water moving. In the First Hydro-geologic System the general mineralization can reach $9 \mathrm{~g} / \mathrm{l}$, in the Second System it goes from 4-20 g/l, in the Third one from 4-50 g/l and in the Fourth System from $0.8-30 \mathrm{~g} / \mathrm{l}$.

Apart from the dissolved minerals, the quality of the water greatly depends on the ion structure. There is a great number of chemical elements, dissolved in different concentration, in the subterranean water. Some components can be found in all subterranean waters and they are referred to as "macro components" ( $\left.\mathrm{Na}, \mathrm{Ca}, \mathrm{Mg}, \mathrm{HCO}_{3}, \mathrm{Cl}\right)$, while the others are found in small quantities and are referred to as "micro components". Nevertheless, the micro compo- nents can have important influence on the medical features of the water and be the main criterion for distinguishing different kinds of thermal-mineral water. Thus we have Sulphur, lodine, Arsenic water, radioactive water, etc. Considering its spa effect, the mineral water can be characterized according to the prevailing ion structure of the water (the chemical type of the water), (Udicki, 1985).

The type of water in Banat mostly depends on the srtatographic level of collectors. Thus, the First System water belong to the $\mathrm{HCO}_{3}-\mathrm{Na}$ type, the Second System water belongs to the $\mathrm{HCO}_{3}-\mathrm{Cl}-$ $\mathrm{Na}$ type, the Third System water belongs to the $\mathrm{Cl}-\mathrm{Na}$ type (rarely, it belongs to the $\mathrm{Mg}$ or Ca type), and the Fourth System water also belongs to the $\mathrm{Cl}-\mathrm{Na}$ type (rarely to the Ca type), (Tomic et al, 1989). A number of medical experts represent the opinion that certain pharmacological components can be given to the patient in the required doses and, therefore, some kinds of medical thermal-mineral water can be substituted by medicines. However, if we carefully analyze the procedure of medical treatment by thermal-mineral water, we can notice that spa treatments have complex effect on human body and spirit.

Thermal-mineral water of Banat contains different pharmacological components: sulphur hydrogen, lodine, Bromine, Boron, Strontium, Lithium, etc. The concentration of medical components is generally high enough to consider the water healing, according to international standards. Banat is rich with thermal-mineral water which contain lodine, Sulphur-hydrogen, Arsenic, Lithium and Boron (Alimpic, 1989).

Previous researches have shown that water in Banat generally contains dissolved gases in the amount which varies from $0.5-1.5 \mathrm{~m}^{3}$ of gas/ $\mathrm{m}^{3}$ of water. Most commonly this gas is methane, but we can also find nitrogen, carbon dioxide, Sulphur-hydrogen, etc. The presence of methane creates great difficulties in the process of water exploitation, because it can be explosive in certain conditions. Sulphur hydrogen is a very interesting component of thermal-mineral water of northern Banat, and together with carbon dioxide, it can cause corrosion of the metal equipment in the borehole (Basic et al, 1988).

In spa treatments, the temperature of water is an important factor. However, the temperature itself, without the medical components in the water, cannot make the water healing. The temperature is only an additional favorable characteristic of mineral water. The temper- ature of the thermal-mineral water of the north Banat is high enough for the purposes of spas, tourism and sport.

There are still many technical, economical and ecological problems when it comes to more intensive exploitation of the thermal-mineral water in Vojvodina. Some of those problems, like corrosion and appearance of methane and mineral sediments, are already mentioned.

The Banat thermal-mineral water contains dissolved salts and gases in different ion ratios. Some of them have destructive effect on metal and cement. The aggressive substances are sulphur hidrogen, carbon dioxide and sodium chlorid. The process of corrosion is intensified by the high temperature of the water. The concentration of aggressive substances in the thermal-mineral water of the First System is small and its destructive effect on the cement is minor. Therefore, the equipment for this system does not have to be made of special and expensive materials, which is not the case with the deeper systems featuring highly mineralized water. Sedimentation of minerals appears in the water which contains carbonates, i.e. hydro-carbonates, which is very common for the Banat thermal-mineral water. The reason for this phenomenon is the violation of chemical balance in the water which disturbs the balance of carbon acid and leads to the separation of calcium carbonate which settles on the walls of borehole and the surface installations. The chemical balance of the water gets disturbed when the pressure or temperature falls drastically or when the water becomes turbulent. Apart from calcium carbonate, the extractable substances are: magnesium carbonate, silicats, oxides, etc. Due to the low level of mineralization and raised concentration of carbon acid, thermal-mineral water of the First System does not usually deposit mineral sediments and, therefore, the precautionary measures are not necessary. The water from all other systems, except for the Fourth System water from south and east Srem and west Backa, tends to deposit mineral sediments in considerable amounts (Udicki, 1985).

The presence of methane in thermalmineral water is more of an economical problem than a technical one. The solution to this problem requires additional equipment which is very expensive. More or less, the thermal-mineral water of Banat contains methane. In the exploitation process, while the water is being pulled up to the surface, the pressure falls and methane is extracted in the form of bubbles (free methane is 
created). In cases when thermal-mineral water is used in closed space, it is possible for the concentrated methane to create explosive mixture. To prevent this, some expensive equipment must be used (Milosavljevic et al, 1984).

The storage of used (cooled) thermalmineral water is one of the major problems in the exploitation process. The water of Vojvodina generally contains mineral substances. Some of them, if released in rivers, canals, lakes and ponds, can violate ecological system because of their negative effect on flora and fauna. The water with high concentration of Sodium, chloride and phenol is particularly suitable for storage. In the previous period, this problem has always been carefully considered. Therefore, people have used only the thermal-mineral water which is not dangerous for nature. Today, the researches and experiments are conducted which aim to solve this problem by bringing the used thermal-mineral water back to its original collector (Milosavljevic et al, 1984).

\section{Thermal-mineral water of northern Banat}

The northern Banat (north of the Begej river) is rich with thermal-mineral water. For now, there are seven hydro-thermal boreholes in this area. Three of them are used today $(\mathrm{Mk}-1 / \mathrm{H}$, Ki-2/H, Vs- $1 / \mathrm{H})$, one is still in the construction phase (Vs$2 / \mathrm{H}$ ), one is temporarily closed (Sm$1 / H)$, one is still in the research phase because of the great amount of gases $(\mathrm{Ki}-4 / \mathrm{H})$ and one is closed because of the high concentration of phenol.

The Sm-1/H ("Sumice") borehole was build in order to provide thermalmineral water to a sport center which was planned but, eventually, not built. The borehole is $950 \mathrm{~m}$ deep. The layer of sand goes from $865 \mathrm{~m}$ to $926 \mathrm{~m}$. It gives 6.2 I of water per second, the temperature of water being $50^{\circ} \mathrm{C}$. Test bottling has given the positive results, but there was no company at the time interested in exploitation. Eventually, the water was used for heating. The thermal-mineral water heats the water in radiators and later is deposited in the near-by canal. The exploitation of this hydro-thermal system for the purpose of heating saved over 150 tons of crude oil a year (Udicki, 1985).

The amount of water given by the rest of the hydro-thermal boreholes located in the Kikinda region varies from 6.2 to $16.7 \mathrm{l} / \mathrm{s}$. The boreholes in the "Sumice" complex give from 6.2 to 15.2 liters of water per second. The water pressure at the surface of the boreholes varies from 0.25 to 1.5 bar (Marinovic,
Stankovic, 1979).

Geothermal characteristics of terrain depend on several factors: thickness of the earth's crust, conduction of heat through rocks, igneous and tectonic activities, intensity of natural radioactivity and oxidation process.

In the area of northern Banat, the geothermal gradients vary from 4.5 to $5.4^{\circ} \mathrm{C} / 100 \mathrm{~m}$, and geothermal degree varies from $18-20 \mathrm{~m} /{ }^{\circ} \mathrm{C}$. Before the measuring was conducted, the borehole had stayed untouched for several months, so that the stable geothermal balance between all the relevant factors was established.

Hydro-thermal system: Mk-1/H (Mokrin), Ki-1/H (Kikinda) and Vs$1 / \mathrm{H}$ (Veliko Selo) represents three different boreholes. Their main purpose is getting hot water for heating the stables and pig farms. Hydro-thermal layers are in the depth between 925 and 1,200 $\mathrm{m}$. The boreholes give between 6.2 and $10.5 \mathrm{l} / \mathrm{s}$ of water, the temperature of which goes from $43-51^{\circ} \mathrm{C}$. These boreholes have been used for almost ten years now without a pause. The facilities are air-heated on the water-air principle. Thermal water heats the air; when cold, the water is deposited into the near-by canals and the fans direct the warm air into the facilities. This heating system saves 1,155 tons of crude oil a year. However, the system could be used even more rationally: the deposited water $\left(25^{\circ} \mathrm{C}\right)$ could be used for sanitary facilities and, during the summer, the cold water could be used for cooling the air (Bogdanovic et al., 1997).

The Vs-2/H (Veliko Selo) borehole. The original plan was to use the thermal water for heating the offices in Veliko Selo. The borehole was finished, inspected and equipped but, eventually, it was never activated due to some financial and technical problems.

\section{The Rusanda Spa}

The spa is based on the mud baths from the Rusanda Lake and the thermal water from the Me- $1 / \mathrm{H}$ borehole, both being near the spa.

The lake has fluvial origin and a semicircular shape. It occuppies the area of $4 \mathrm{sq} \mathrm{km}$ and it is only $1.5 \mathrm{~m}$ deep (Bajic, 1964). The water in the lake is salty but the salinity is not the same in all parts of the lake. The level of salinity is higher in the places where the salt-water springs appear from the bottom of the lake. The chemical analysis of the lake water gave the following results:

- the water is slightly acidic (pH 6.8)

- the material which remains after the evaporation is $15.68 \mathrm{~g} / \mathrm{l}$
- the total mineralization is $16.539 \mathrm{~g} / \mathrm{l}$

- distinctive ions (in $\mathrm{g} / \mathrm{l}$ ) are: Natrium 5.8, Calcium 0.24, hidro carbonate 1.464, chlorides 8.52 and sulphate 0.341 .

- the medicinal substances are: Fluorine, Bromine, lodine, Iron, SulphurHydrogen, Lithium, Barium, Strontium, Arsenic, Radon and carbon-dioxside. The water is described as alkaline and saline. It is muddy and yellow because of the presence of humus. The average salinity is $4 \%$, but this value varies from one season to another: it is higher in summer than in winter (Laskov, 1982).

The bottom of the lake is covered with a thick layer of mud. Its average thickness is $1 \mathrm{~m}$ but, at the places where salt-water springs appear, it can be even $2 \mathrm{~m}$ thick. The mud from the lake is black and shiny. It sticks to skin very well, which is an important feature since the therapy implies covering one's skin with the mud. It smells of SulphurHydrogen. Apart from organic substances, the mud contains: hydro-carbonates, carbonates, sulphates, Sulphur-Hydrogen, chlorides, $\mathrm{K}$ and $\mathrm{Na}$, Silicon-dioxide, $\mathrm{Fe}$ and Aluminium-oxide. Unlike the lake water, the mud is alkaline $(\mathrm{pH}$ 8), (Bajic 1964).

Hydro-thermal borehole Me-1/H (Melenci), made in 1978, is located right next to the lake and the spa park. It was built with the intention to examine the possibility of using the thermal-mineral water of this area. The water was found $1,095 \mathrm{~m}$ under the ground. Its temperature is $69^{\circ} \mathrm{C}$ and the chemical analysis has shown the following:

- the water is alkaline ( $\mathrm{pH}$ 8.6)

- sedimented minerals: $2.591 \mathrm{~g} / \mathrm{l}$

- distinctive ions: $\mathrm{Na}$, hydro-carbonate and chloride

- medicinal substances: Fe

Due to its high temperature and mild mineralization, this water is used in spa baths and pools. It would be possible to use it for heating, too.

The lake mud has been used for medicinal purposes since the middle of the last century, but more intensly since 1875. Originally, it was used for treating different skin diseases and, only later, people started using it for various rheumatic pains. In 1963, the Rusanda spa became a center for physical medicine and rehabilitation (Cigulov, 1974).

\section{Hydro-thermal water of Jermenovci}

On the outskirts of the Jermenovci village, in the southeast Banat, there is a borehole called Je-17. Originally, it was used for removing the oil from the earth. After the oil had been completely ex- 
hausted, the well was used for the exploitation of the thermal-mineral water. In 1973, the first thermal-mineral water was drawn up from the depth of 700-800 $\mathrm{m}$. The borehole gives 300 I of water per minute, and the temperature of the water is $48^{\circ} \mathrm{C}$. The chemical analysis has shown the following:

- the water is slightly alkaline ( $\mathrm{pH} 7.6)$

- the amount of settled minerals is $15.674 \mathrm{~g} / \mathrm{l}$

- distinctive ions (g/l) are: $\mathrm{Na}$ (4.8) and $\mathrm{Cl}(9.335)$

- the medicinal substances: Bromine, lodine, Hydrogen-sulphate, Strontium, Iron and Barium (Aksin, 1976)

The scientists from the "Boris Kidric" Institute in Vinca have measured the radioactivity of the water $(88 \mathrm{pCi} / \mathrm{l})$ and concluded that it comes from Radium-226, Radon and $\mathrm{K}^{40}$. Although the level of radioactivity is high, the water can be used for the spa baths. The researchers have also determined the contents of microelements. The water of Jermenovci is known as the most radioactive and the lodine-richest water in the whole Vojvodina. It is considered to be one of the most healing waters in Serbia. Baths are used for treating various rheumatic pains. There are two pools: one for the purposes of therapy and the other, in the open, for recreation. For the time being, the spa building is closed for the visitors. However, this is only temporary: according to the urban plan made for this area, this place will be developed into a complex tourist center.

\section{Torda - The Bitter Water}

Torda is a village located $40 \mathrm{~km}$ north of Zrenjanin. In 1924, while the locals were making a well, a gust of water suddenly sprang out from the depth of $15 \mathrm{~m}$. Later, it was established that the water is mineral and the exploitation began: the water was bottled and sold. Beside this well called "St. George", another one was drilled - much deeper (230 $\mathrm{m})$ and called "Jordan". Although cold, the water from these two wells is highly mineralized: the "St. George" water - $7.871 \mathrm{~g} / \mathrm{l}$ and the "Jordan" water $11.669 \mathrm{~g} / \mathrm{l}$. The water contains sulphates which gives it the bitter taste. Regarding chemical structure and medicinal features, the water from Torda differs significantly from all the other kinds of healing water found in the area. The Torda water belongs to the $\mathrm{Na}$ and $\mathrm{Mg}$ sulphate type with very small amount of $\mathrm{Cl}$ (Bogdanovic et al. 1997).

On $4^{\text {th }}$ November 1957, the authorities stated that the water from Torda is drinkable. Several scientific institutions conducted the detailed analyses which gave the positive results. It is concluded that the water can cure liver damages, piles and some minor stomach problems (Laskov, 1982).

\section{The Bitter Water - Lazarevo}

The village of Lazarevo is on the east from Zrenjanin. The first borehole was drilled in 1931, and soon after that the exploitation began, with a help from some German investors. The water was bottled and sold as "Bitter Wasser - Lazarevo". It was very helpful in treating stomach illnesses (Bogdanovic, 1995). By the end of the World war II, the German investors left the country and the exploitation was stopped. After the war, the scientists concluded that the Lazarevo mineral water belongs to the type of bitter water. However, its exploitation has never been revived.

\section{Conclusion}

Regarding the features of thermal-mineral water on the Banat territory and having in mind the cases of similar areas around the world, we can conclude that the mineral water of Banat can be used in the following ways: for spa treatments and therapies, for the purposes of sport and recreational centers, in agriculture - for heating hothouses, for keeping livestock (heating the stables), in industry - as technical hot water, for providing flats with sanitary hot water and, finally, in fishing.

The most important reason for the exploitation is the usage of this water in spas and recreational centers with local contractive zones. This conclusion comes from the fact that the choice of healing water indications is relatively limited and that the tourist contractive zones are rather small. The only spa center which can compete with the spas of central Serbia, regarding the tourist offer, is Rusanda.

\section{References}

Bukurov, B. (1974): Bačka, Banat i Srem, Matica srpska, Novi Sad

Fond stručne dokumentacije NIS NAFTAGAS, Novi Sad

Bajić, M. (1964): Banja Rusanda, Matica srpska, Novi Sad

Aksin, V., Milosavljević, S. (1982): Geotermalni potencijali SAP Vojvodine, Istraživanje i korišćenje, Novi Sad

Baić, Đ., Milosavljević, S., Vidović, S. (1988): Korišćenje niskotemperaturnih voda bogatih gasovima, Zbornik radova, Adana (Turska)

Marinović, Đ., Stanković, S. (1979): Termomineralni gradijenti i početni slojni pritisci u prepliocenskom geološkom kompleksu Vojvodine, Zbornik radova sa naučnog skupa, Zagreb

Tomić, P., Romelić, J. (1999): Mineral and Thermal Waters of Srem, Present and Perspective Usage, Geographica Pannonica, International Scientific Journal, No. 3, Institut za geografiju, Prirodno-matematički fakultet, Novi Sad, strana 8-12.

Romelić, J., Tomić, P. (1995): Specifični uslovi razvoja banjskog turizma u Vojvodini i mogućnosti za njihovu optimalnu valorizaciju, Zbornik radova sa Naučnog skupa Banjska i klimatska mesta jugoslavije, Vrnjačka Banja, 5-7. oktobar 1995, strana 473-478.

Vuković, M., Soro, A. (1989): Dinamika podzemnih voda, Geološki anali, Beograd

Alimpić, S. (1989): Uslovi i mogućnost iznalaženja geotermalne energije Vojvodine, Savetovanje o termoenergiji, Beograd

Udicki, A. (1985): Geotermski potencijali prvog hidrogeološkog sistema na području Kikinde, NIS Naftagas, Novi Sad

Bogdanović, Ž., and eth. (1997): Termal water Banat' s, Banat, Geographic Monographis of European regions, University of Novi Sad, West University of Temisoara, Jozsef Attila University Szeged. 